\title{
CORPORATE GROWTH AND TOTAL FACTOR PRODUCTIVITY IN INDUSTRIAL COMPANIES
}

\author{
S. Konstantinova*, A. Konarev \\ Faculty of Economics, University of Food Technologies - Plovdiv, Bulgaria
}

\begin{abstract}
The purpose of the study is to reveal the availability, the type and the rates of corporate growth in certain industrial companies. The role and the relative influence of the total factor productivity in this growth are also determined. The methods and the models of the production functions for analysis and forecasting are offered. Specific factors and opportunities for the increase rates of corporate growth are revealed. The decisive role of the total factor productivity for the development of industrial companies in Bulgaria is demonstrated.
\end{abstract}

Key words: industry, company, growth, model, productivity

\section{INTRODUCTION}

The economic growth is a decisive factor and an indicator for the development of the national and global economy. Its foundation is formed by the corporate growth - the growth of the main business unit. Along with the traditional factors of labour and capital, there is a third factor that leads to an increase in production and can be called "technological progress". In this case, the word "technology" is used in a broad sense, meaning that the technological progress is the use of new technological operations, processes, materials, new combination of resources, new forms of organization, new marketing methods, etc. In this context, corporate growth can be seen as the result of three main factors (labour, capital, technology) and can be presented in the following way:

$$
C g=F(L, C, T),
$$

where $C g$ is corporate growth;

$L$ - labour;

$C$ - capital;

$T-$ technology.

In recent years, under the conditions of an ongoing industrial revolution, interesting processes have been observed. According to Klaus Schwab (1) over the past decade, the

\footnotetext{
*orrespondence to: Assoc. Prof. Snezhinka Konstantinova Stoyanova, PhD, Faculty of Economics, University of Food Technologies Plovdiv, Bulgaria, Cell Phone: +359 878 384372, E-mail: sks_ko@abv.bg
}

productivity across the globe (whether measured as labour productivity or total factor productivity - TFP) remains stagnant despite the exponential increase in technological progress and investments in innovation. $\mathrm{He}$ refers to data collected by The Conference Board (2), according to which the global labour productivity growth in the period 1996 - 2006 is an average of $2.6 \%$, compared to $2.1 \%$ in 2013 and 2014. In the leading economy in the world - that of the United States, there is an even greater decline in growth, with the major portion of this decline due to TFP, which is the result of technology and innovation. Thus, for the period $1995-$ 2007 , the annual growth rate of TFP is $1.4 \%$ and for the period $2007-2014$ it is only $0.5 \%$ (3). These facts show that technological innovations fail to deliver higher levels of productivity. They are one of the great economic puzzles of modern times, which precede the global recession and for which there is no satisfactory explanation (1).

\section{MODELS, RESULTS AND DISCUSSION}

In the context of these changes, the behaviour of the main business units of the Bulgarian economy - companies and especially those from the industrial sector - is of special research interest. For this reason, a random sample of 30 industrial companies is formed by all industrial companies traded on the Bulgarian Stock Exchange (BSE - Premium Shares and Standard Shares segments) and the Alternative Market (BaSE - Shares segment). The period for which corporate growth is analyzed is $2010-2016$. The selection of 2010 
as the beginning of the analyzed period is dictated by our opinion that after the crisis of 2007 - 2008 the companies sharply changed their economic rhythm. We assume that to some extent in 2010 they experienced the shock of the crisis and stabilized their activities.

The analysis of the economic results of the sample of 30 companies showed that in 10 of them, corporate growth was achieved $(33.33 \%)$. It is well known that corporate growth can be measured by different indicators (6). In this case, the amount of total revenue is used as a growth indicator. In order to realize the main purpose of the research for establishment of the role of the individual factors in corporate growth, namely that part thereof that is due to the technological progress, the approach of Robert Solow (4) was applied, who uses the two-factor Cobb Douglas production function of the following type:

$Y t=A t \cdot F(K t, L t)$,

where $Y t$ is aggregate production;

$K t$ - the amount of physical capital used in production;
KONSTANTINOVA S., et al. $L t$ - the amount of labour resources employed; $A t-$ technological level.

After the transformation, the calculation model of the "Solow's balance" is obtained in the following form:

$$
\frac{A_{t}}{A_{t}}=\frac{Y_{t}}{Y_{t}}-a_{t} \frac{K_{t}}{K_{t}}-b_{t} \frac{L_{t}}{L_{t}},
$$

where $a t$ is the share of capital costs in the total costs;

$b t$ - the share of labour costs in the total costs.

The type of real-time data model has the following form (5):

$$
\frac{\Delta A_{t}}{A_{t-1}}=\frac{\Delta Y_{t}}{Y_{t-1}}-a_{t} \frac{\Delta K_{t}}{K_{t-1}}-b_{t} \frac{\Delta L_{t}}{L_{t-1}},
$$

This model has been used by Robert Solow and many other researchers to determine the total factor productivity at national level. The main challenge for us was to try to apply the basic structure of the Solow model in order to determine the total factor productivity at the level of the individual company. For this purpose we transformed the model into the following form:

$$
\frac{A_{t}^{i}-A_{t-n}^{i}}{A_{t-n}^{i}}=\frac{Y_{t}^{i}-Y_{t-n}^{i}}{Y_{t-n}^{i}}-C d_{i} \frac{K_{t}^{i}-K_{t-n}^{i}}{K_{t-n}^{i}}-L a_{i} \frac{L_{t}^{i}-L_{t-n}^{i}}{L_{t-n}^{i}},
$$

where $C d i$ represents the capital demand of the production of the i-th company for the relevant period - elasticity of revenues in terms of capital costs;

$L a i$ - the labour absorption of the production of the i-th company for the same period elasticity of revenues in terms of labour costs; $n-$ duration of the analyzed period in years.

Table 1 was compiled on the basis of the actual costs of the companies for labour and capital for the period $2010-2016$. The labour and capital demand indicators presented in Table $\mathbf{1}$ are defined in two options, as follows:

Table 1. Capital demand and labour absorption of the growth of industrial companies

\begin{tabular}{|l|c|c|c|c|}
\hline \multirow{2}{*}{$\begin{array}{c}\text { Industrial } \\
\text { companies }\end{array}$} & \multicolumn{2}{c|}{ Capital demand } & \multicolumn{2}{c|}{ Labour absorption } \\
\cline { 2 - 5 } & Average & Incremental & Average & Incremental \\
\hline 1. Monbat AD & 0,9174 & 0,4820 & 0,0358 & 0,0212 \\
\hline 2. Neochim AD & 0,7818 & 0,3698 & 0,0953 & 0,3018 \\
\hline 3. Biovet AD & 1,2854 & 1,8135 & 0,0986 & 0,1105 \\
\hline 4. Trace Group Hold AD & 1,0388 & 2,3721 & 0,0356 & 0,2596 \\
\hline 5. Alcomet AD & 0,8372 & 0,6986 & 0,0600 & 0,1061 \\
\hline 6. Zaharni zavodi AD & 1,5711 & 0,2488 & 0,1043 & 0,1343 \\
\hline 7. Yuri Gagarin AD & 0,9994 & 0,5843 & 0,0947 & 0,0440 \\
\hline 8. EMKA AD & 0,2942 & 1,7226 & 0,0410 & 0,1959 \\
\hline 9. Lavena AD & 1,1922 & 1,1130 & 0,0864 & 0,0597 \\
\hline 10. Unipack AD & 1,0425 & 3,86668 & 0,0714 & 0,1983 \\
\hline
\end{tabular}

The labour and capital intensity indicators presented in Table $\mathbf{1}$ are defined in two options, as follows:
1. Capital demand:

a) average - defined as the ratio of the average capital costs to the average economic result;

b) incremental - the additional capital invested during the period $2010-2016$ is divided 
KONSTANTINOVA S., et al.

by the additional result for the same period.

2. Labour absorption:

a) average - average labour costs to average economic result;

b) incremental - additional labour costs for the period 2010 - 2016 to additional labour.

It is necessary to point out that the labour intensity is not measured in the classical way as labour costs expressed in normal hours (man-hours) for the production of a unit of output, but as labour costs expressed in wages and social security contributions at the expense of the employer.

Defined in two versions, Cdi and Lai data enable the increase in total factor productivity also to be determined in two variants of the model (4). For the purposes of this study, the first option with the average labour and capital intensity indicators is used. On the basis of this model, the contribution of the labour, capital and total factor productivity to the corporate growth of industrial companies was determined - Table 2:

Table 2. Contribution of capital, labour and total factor productivity to corporate growth

\begin{tabular}{|l|c|c|c|c|}
\hline \multicolumn{1}{|c|}{ Industrial companies } & $\Delta \mathbf{Y} / \mathbf{Y}$ & $\mathbf{C d} . \Delta \mathbf{K} / \mathbf{K}$ & $\mathbf{L a} \cdot \Delta \mathbf{L} / \mathbf{L}$ & $\Delta \mathbf{A} / \mathbf{A}$ \\
\hline 1. Monbat AD & 0,8543 & 0,3070 & 0,0138 & 0,5335 \\
\hline 2. Neochim AD & 0,5575 & 0,1819 & 0,0616 & 0,3140 \\
\hline 3. Biovet AD & 0,8285 & 1,8106 & 0,0096 & $-0,9917$ \\
\hline 4. Trace Group Hold AD & 0,1406 & 0,3667 & 0,0654 & $-0,2915$ \\
\hline 5. Alcomet AD & 0,3806 & 0,2578 & 0,0473 & 0,0750 \\
\hline 6. Zaharni zavodi AD & 0,3500 & 0,0762 & 0,0495 & 0,2243 \\
\hline 7. Yuri Gagarin AD & 1,4135 & 0,6385 & 0,0451 & 0,7299 \\
\hline 8. EMKA AD & 0,3058 & 0,0596 & 0,1438 & 0,1024 \\
\hline 9. Lavena AD & 3,3128 & 3,3211 & 0,1310 & $-0,1393$ \\
\hline 10. Unipack AD & 0,1607 & 0,7942 & 0,0372 & $-0,6707$ \\
\hline
\end{tabular}

The symbols used in Table 2 are as follows: $\Delta Y / Y$ - corporate growth;

$C d . \Delta K / K-$ contribution of capital to corporate growth;

La. $\Delta L / L-$ contribution of labour to corporate growth;

$\triangle A / A$ - contribution of total factor productivity to corporate growth.

The comparative analysis shows that in almost all companies the capital contribution is significantly higher than the labour contribution. An exception is the results of the company for the production of enamelled bobbins, profiled and insulated cables and conductors from EMKA AD, City of Sevlievo. The specific analysis shows that the investment rate of this company in labour significantly exceeds those in capital. The differences in the contributions of the two main factors (labour and capital) to corporate growth are due to some extent to the low cost of labour in our country. It is necessary to distinguish between the terms "cost for labour" and "labour costs". In the model used to determine total factor productivity (4), the contribution of labour is determined on the basis of the labour costs.

The data presented in Table 2 relate to the whole analyzed period $2010-2016$, which is why they are not indicative of the annual growth rates. If the average annual results are analyzed, Table 3 is obtained:

Table 3. Average annual growth rate of corporate growth and total factor productivity

\begin{tabular}{|l|c|c|}
\hline \multicolumn{1}{|c|}{ Industrial companies } & Corporate growth $(\%)$ & Growth of TFP (\%) \\
\hline 1. Monbat AD & 14,24 & 8,89 \\
\hline 2. Neochim AD & 9,29 & 5,23 \\
\hline 3. Biovet AD & 13,81 & $-16,52$ \\
\hline 4. Trace Group Hold AD & 2,34 & $-4,86$ \\
\hline 5. Alcomet AD & 6,34 & 1,25 \\
\hline 6. Zaharni zavodi AD & 5,83 & 3,74 \\
\hline 7. Yuri Gagarin AD & 23,56 & 12,17 \\
\hline 8. EMKA AD & 5,10 & 1,71 \\
\hline 9. Lavena AD & 55,21 & $-2,32$ \\
\hline 10. Unipack AD & 2,68 & $-11,18$ \\
\hline
\end{tabular}

The data in Table 3 reveal significant fluctuations between the individual industrial companies, both in terms of corporate growth and total factor productivity. The average level of corporate growth for all companies surveyed 
KONSTANTINOVA S., et al.

is $11.49 \%$ and the standard deviation is $9.82 \%$. The average growth rate of total factor productivity is $-1.89 \%$ and the standard deviation is $7.26 \%$.

Very high corporate growth $(55.21 \%)$ is reported by Lavena $\mathrm{AD}$ - company for natural products from lavender and herbs. During the analyzed period, its activity expanded and gradually workshops were constructed to the distilleries for various cosmetic products creams, shampoos, toothpastes, etc. The continuous drive for development led the company to the next, higher level - production of food supplements and medical devices.

High corporate growth (23.56\%) was achieved by Yuri Gagarin AD - company for the production of multicoloured printed packages, cigarette filters and labels from cardboard and paper for the cigarette, food, cosmetic and other industries. In recent years, the company has significantly increased the production and sale of filters. Relatively high corporate growth is reported by the dynamically developing industrial companies Monbat AD, Biovet AD and Neochim AD.

The analysis of the growth of TFP shows that negative values were recorded in four companies. This result can hardly be seen as a downgrade of the technological level of the activity therein.

According to the authors, this is due to the specificity of the calculation of the growth of the total factor productivity as the remainder derived from the growth rate of corporate growth by subtracting the rate of capital costs and labour costs.

The comparison of the contribution of the three main factors (capital, labour and TFP) shows that the capital costs are the main determinant of corporate growth in the industrial companies. The impact of labour on growth is weak. The total factor productivity is the most unstable of the three corporate growth factors for the period $2010-2016$.

\section{CONCLUSIONS}

The study allows for the following conclusions to be drawn:

1. Corporate growth in industrial companies is formed by three main factors: labour, capital and technology. The authors use the "technology" factor as a synonym for the total factor productivity that reflects the impact of all corporate growth factors that are not changes in the capital and labour costs.
2. By analogy to macroeconomic surveys of the economic growth of the national and the world economy, the two-factor Cobb Douglas production function was used for the assessment of the corporate growth at micro level - the industrial company. The authors believe that the model should be improved by defining a parameter for elasticity of corporate growth from the total factor productivity.

3. The conducted survey of a random sample of 30 industrial companies traded on the main and alternative markets of the BSE showed that only $33.33 \%$ of them have achieved corporate growth during the period 2010 2016. In addition, large fluctuations are emerging between companies, both in terms of corporate growth and total factor productivity. These results are unfavourable because they show that the Bulgarian industry still cannot overcome the shock of the World recession in $2007-2008$ and to move on the road to economic growth.

4. The analysis of the contribution of the three major factors (capital, labour and TFP) to the corporate growth of specific industrial companies shows that capital costs are the main factor of growth. The impact of labour is relatively weak. The total factor productivity is the most unstable of the three factors of corporate growth and it has had a negative effect. This result is quite disturbing given the limited capital and labour resources and the high expectations of the technological progress.

\section{REFERENCES}

1. Schwab, K. The Fourth Industrial Revolution. Plovdiv: Publishing house Hermes, 2016, p. 51.

2. The Conference Board, Productivity Brief, 2015. - www.conference-board.org.

3. United States Department of Labor. Preliminary Multifactor Productivity Trends, 2014.

https://www.dol.gov/olms/regs/compliance/l m3_downloadpg.htm

4. Solow, R. M. Technical Change and the Aggregate Production. Review of Economics and Statistics, Vol. 39, №3, (Aug., 1957), pp. 312-320.

5. Ganev, K. Measuring Total Factor Productivity: Growth Accounting for Bulgaria. Discussion papers of the BNB, DP / 48/2005, pp.8-9. ISBN 954-9791-84-X

6. Konarev, A. and Sn. Konstantinova. Analysis of the economic activity of industrial companies. Plovdiv: Publishing house KSI, 2017, p. 227. ISBN 978-954-2924-27-6

7. Todorov, I. The Economic Growth of Bulgaria in the Period of the Currency Board. //Economic Alternatives, Issue 3, 2015. 